\title{
ALTERNATIVE LANDFILL COVER AND MONITORING SYSTEM FOR LANDFILLS IN ARID ENVIRONMENTS
}

\author{
PROJECT CLOSEOUT REPORT
}

\section{Accelerated Site Technology Deployment NV09SS21}

Prepared by

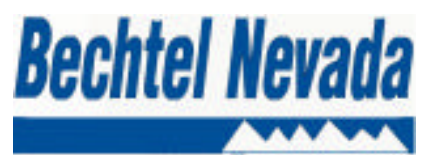

Prepared for

U.S. Department of Energy

National Nuclear Security Administration

Nevada Site Office 


\title{
DISCLAIMER NOTICE
}

Reference herein to any specific commercial product, process, or service by trade name, trade mark, manufacturer, or otherwise does not necessarily constitute or imply its endorsement, recommendation, or favoring by the United States Government or any agency thereof or its contractors or subcontractors.

Available for sale to the public, in paper, from:

\author{
U.S. Department of Commerce \\ National Technical Information Service \\ 5285 Port Royal Road \\ Springfield, VA 22161 \\ Phone: (800) 553-6847 \\ Fax: (703) 605-6900 \\ E-mail: orders@ntis.fedworld.gov \\ Online Ordering: http://www.ntis.gov/ordering.htm
}

Available electronically at http://www.doe.gov/bridge

Available for a processing fee to the U.S. Department of Energy and its contractors, in paper, from:

\section{U.S. Department of Energy}

Office of Scientific and Technical Information

P.O. Box 62

Oak Ridge, TN 37831-0062

Phone: (865) 576-8401

Fax: (865) 576-5728

E-mail: reports@adonis.osti.gov 


\section{CONTENTS}

Acronyms and Abbreviations .................................................................................................

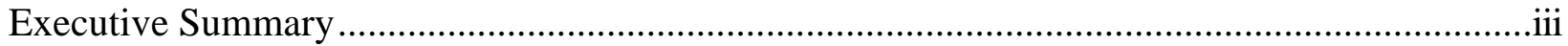

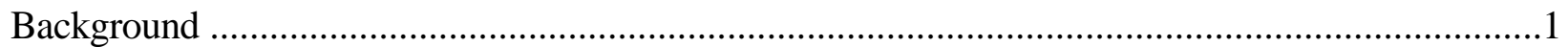

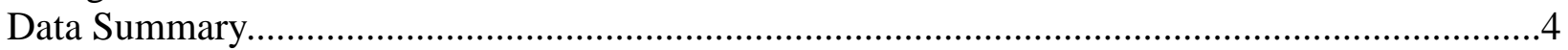

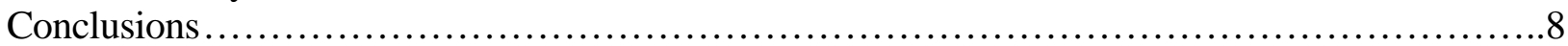

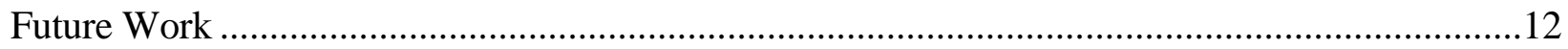

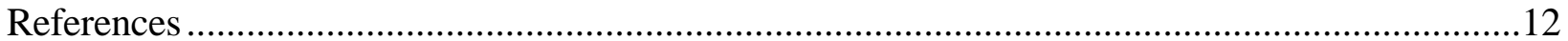

\section{List of Figures}

Figure $1 \quad$ Location of U-3ax/bl and the Drainage Lysimeter Facility ...............................2

Figure 2 Surface treatments of the eight lysimeters (all are now filled with soil).................2

Figure $3 \quad$ Location of sensors within one drainage lysimeter ......................................... 3

Figure 4 Schematic cross-section of sensor locations in the U-3ax/bl closure cover) ............3

Figure 5 Schematic cross-section of sensor locations in each of the eight drainage and

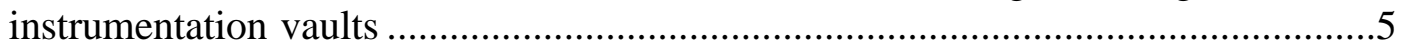

Figure 6 Soil water content in bare drainage lysimeter (A) using TDR system....................7

Figure 7 Soil water content in native vegetated drainage lysimeter (E) using

TDR system...................................................................................

Figure 8 Soil water content in U-3ax/bl cover (west station) using TDR system................9

Figure 9 Soil water content in U-3ax/bl cover (east station) using TDR system ..................9

Figure $10 \quad$ Total soil water storage in drainage lysimeters ............................................. 10

Figure 11 Soil water storage ratio (bare to native vegetated) .......................................... 10

Figure $12 \quad$ Water potential in lysimeter A (bare soil) ................................................ 11

Figure $13 \quad$ Water potential in lysimeter E (native vegetation) ..........................................11

\section{List of Tables}

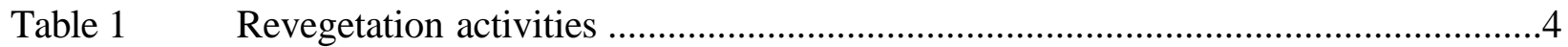

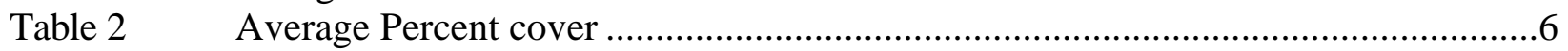

Table $3 \quad$ Plant Density by species......................................................................... 6

\section{Attachments}

Attachment 1 As-Built Drawings for the Area 3 Lysimeter Facility 


\section{ACRONYMS and ABBREVIATIONS}

\begin{tabular}{|c|c|}
\hline $\begin{array}{l}\text { ASTD } \\
\mathrm{cm}\end{array}$ & $\begin{array}{l}\text { Accelerated Site Technology Deployment } \\
\text { centimeter }\end{array}$ \\
\hline DOE/NV & U.S. Department of Energy, Nevada Operations Office \\
\hline ET & Evapotranspiration \\
\hline $\mathrm{ft}$ & foot (feet) \\
\hline FY & fiscal year \\
\hline $\mathrm{m}$ & meter(s) \\
\hline $\mathrm{m}^{2}$ & square meter(s) \\
\hline NNSA/NV & National Nuclear Security Administration Nevada Site Office \\
\hline NTS & Nevada Test Site \\
\hline RCRA & Resource Conservation and Recovery Act \\
\hline RWMS & Radioactive Waste Management Site \\
\hline TDR & Time-Domain Reflectrometry \\
\hline
\end{tabular}




\section{EXECUTIVE SUMMARY}

In December 2000, a performance monitoring facility was constructed adjacent to the mixed waste disposal unit U-3ax/bl at the Area 3 Radioactive Waste Management Site at the Nevada Test Site. This facility consists of eight drainage lysimeters measuring 10 feet in diameter, 8 feet deep, and backfilled with native soil. The lysimeters have three different surface treatments: two were left bare, two were revegetated with native species, and two were allowed to revegetate with invader species (two are reserved for future studies). The lysimeters are instrumented with an array of soil water content and soil water potential sensors and have sealed bottoms so that any drainage can be measured. All sensors are working properly and indicate that the bare lysimeters are the wettest, as expected. The vegetated lysimeters, both seeded and those allowed to revegetate with invader species, are significantly drier than the bare cover treatments. No drainage has occurred in any of the lysimeters. The Accelerated Site Technology Deployment program under the U.S. Department of Energy's Office of Science and Technology provided the funding for this project with the objective of reducing the uncertainty associated with the performance of monolayer-evapotranspiration waste covers in arid regions such as the one deployed at U-3ax/bl. 


\section{Background}

Traditional Resource Recovery and Conservation Act (RCRA) landfill covers are typically layered, including layers of compacted clay and coarse gravel to isolate waste. This type of cover was originally to be deployed for the closure of the U-3ax/bl waste disposal unit located within the Area 3 Radioactive Waste Management Site (RWMS) of the Nevada Test Site (NTS) (Figure 1). Concerns regarding differential subsidence and subsequent shearing of the traditional RCRA-type cover prompted an internal 1997 study to investigate subsidence and closure covers. Findings from this study indicate that a monolayer-evapotranspiration (ET) cover consisting of native alluvium would be most effective in isolating waste under subsidence conditions. Modeling results and a multiple-year data record from a weighing lysimeter facility in nearby Area 5 provide evidence that the use of a partially vegetated monolayer cover will effectively isolate waste from infiltrating water via evapotranspiration back to the atmosphere, even during wetter-than-average years (Levitt et al., 1996 ; Schmeltzer et al., 1996). Additionally, other studies indicate that in the arid southwestern United States, monolayer-ET covers may be more effective at isolating waste than the layered covers because of the tendency of the clay layers to desiccate and crack, thereby creating preferential pathways for infiltrating water (O'Donnell, 1998; Dwyer, 1998). These studies led to the selection of a monolayer-ET cover deployment for the closure of disposal unit U-3ax/bl.

In fiscal year (FY) 1999, the Accelerated Site Technology Deployment (ASTD) program accepted the U.S. Department of Energy's Nevada Operations Office (DOE/NV) proposal to deploy a monolayer-ET closure cover and a performance monitoring system on U-3ax/bl disposal unit at the NTS, Area 3 RWMS. The monolayer-ET cover is an alternative to a layered cover typically specified by RCRA. The monitoring system consists of two parts: instrumentation in the closure cover and instrumentation in an adjacent lysimeter facility (see Figure 1), which allows some parameters to be varied for comparison with physical conditions in the cover. The deployment was jointly funded by the ASTD Program and the DOE/NV. The ASTD program funded construction of the lysimeter facility, whereas the DOE/NV funded construction of the alternative closure cover and its instrumentation.

This facility was constructed such that soil conditions are identical to the closure cover of U-3ax/bl. The lysimeters were constructed to collect and measure any drainage, and thereby provide an indirect measure of drainage though the closure cover. Additionally, the lysimeters were constructed with three surface treatments: two were left bare, two were revegetated with native species, and two were allowed to revegetate with invader species and (two were reserved for future studies) (see Figure 2). The lysimeter facility was funded for the purpose of collecting data to reduce the uncertainty associated with monolayer-ET waste cover performance in arid environments.

Each lysimeter is instrumented with an array of soil water content sensors (time-domain reflectrometry [TDR] probes) and soil water potential sensors (heat dissipation probes) as shown in Figure 3 and Attachment 1. U-3ax/bl is instrumented with soil water content sensors only as shown in Figure 4. All sensors in both the closure cover and lysimeter facility are working properly, with no indication of damage to any sensor during construction. 


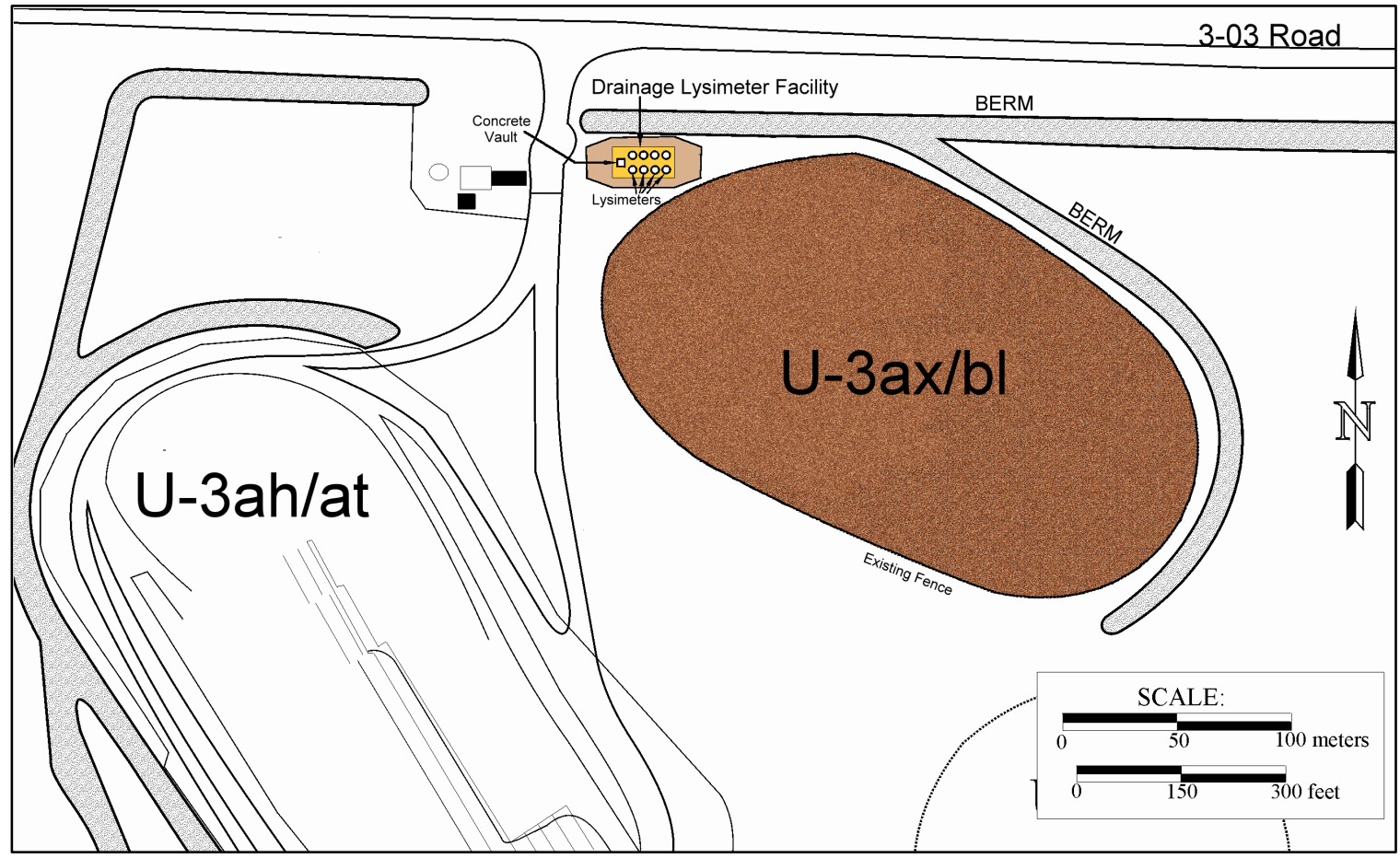

Figure 1 Location of U-3ax/bl and the Drainage Lysimeter Facility

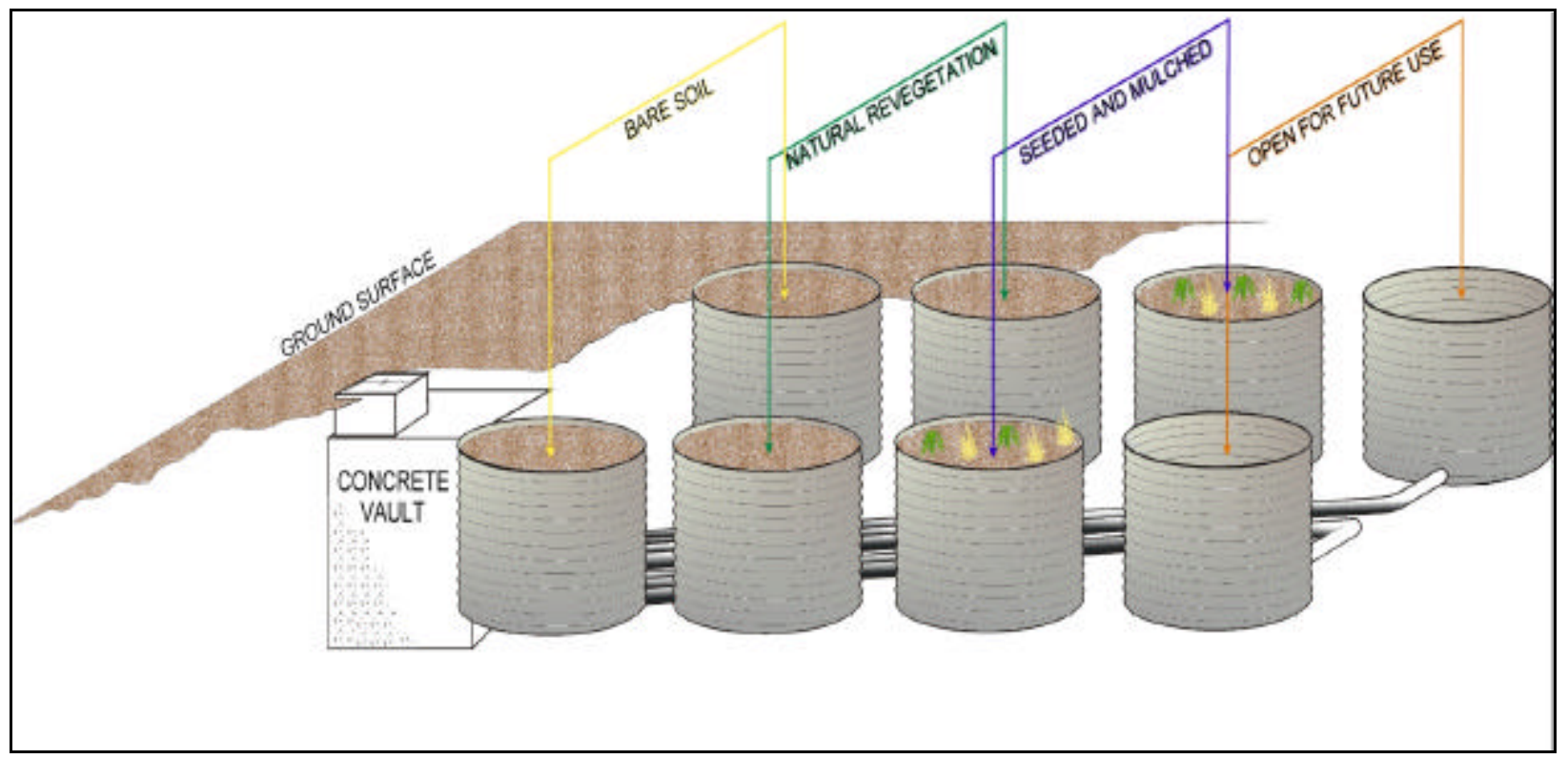

Figure 2 Surface treatments of the eight lysimeters (all are now filled with soil) 


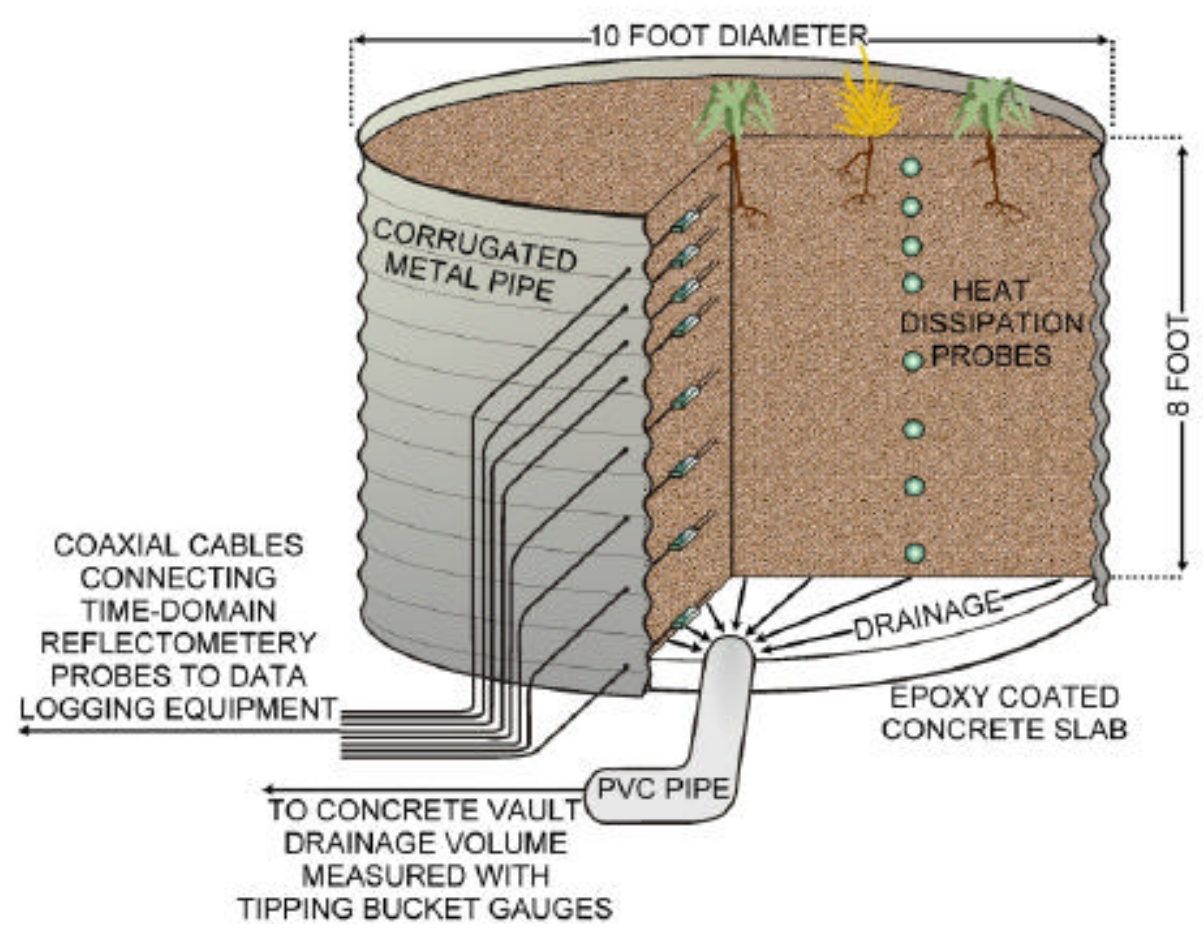

Figure 3 Location of sensors within one drainage lysimeter

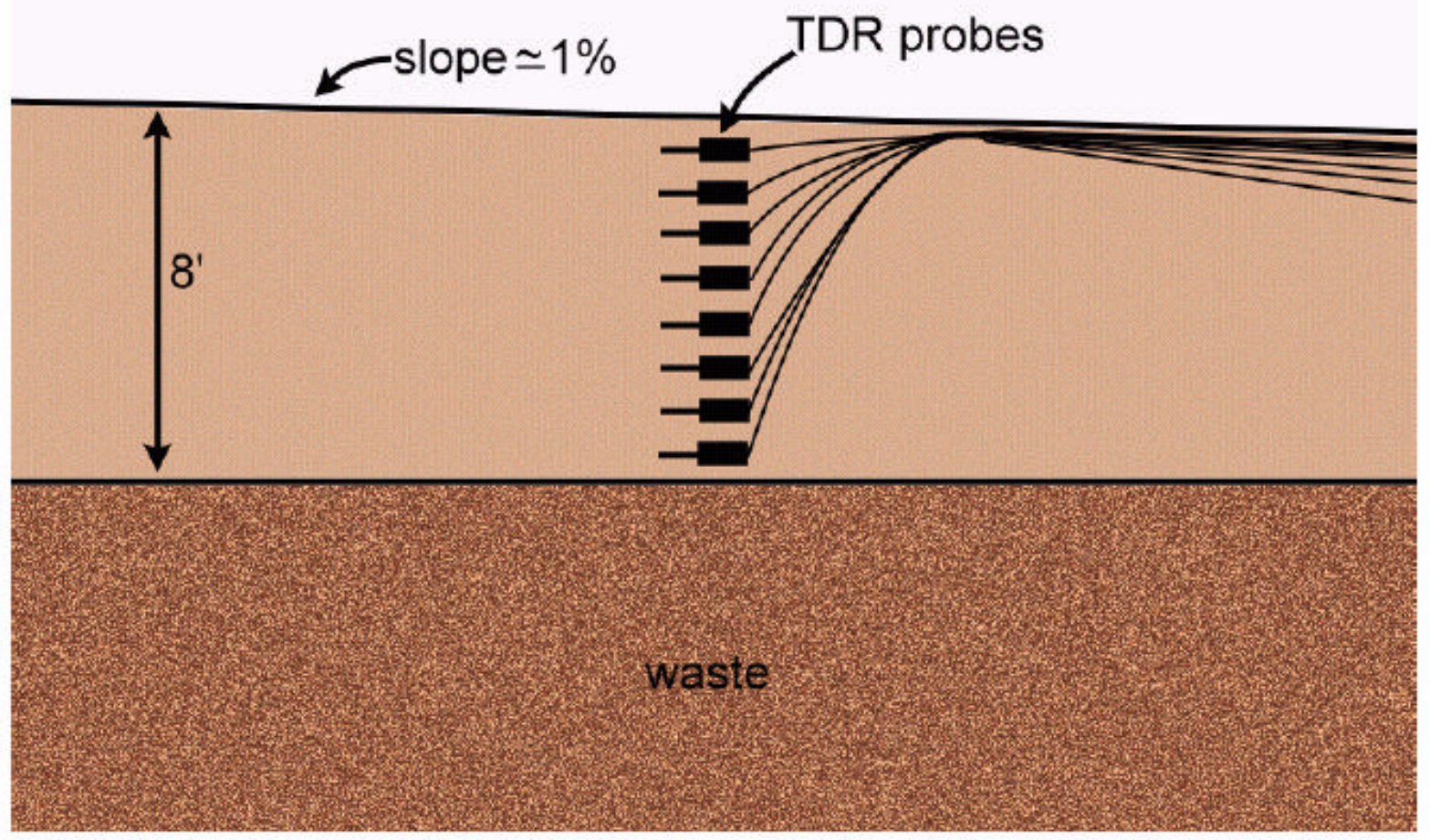

Figure 4 Schematic cross-section of sensor locations in the U-3ax/bl closure cover 
In November 2000, construction of the final closure cover of U-3ax/bl began with the application of 30 centimeters $(\mathrm{cm})(1$ foot [ft]) of soil from a nearby borrow pit to the original 2.4- to 3.0 meter $(\mathrm{m})(8-$ to $10 \mathrm{ft}$ ) thick operational closure cover. The final closure cover ranges in thickness from approximately 2.7 to $3.4 \mathrm{~m}$ (9 to $11 \mathrm{ft})$. Re-vegetation activities began in December 2000 with seeding of native species (see Table 1) and straw mulching of the closure cover and two of the drainage lysimeters. The percentage of each species used in the seed mix is based on the relative contribution of a particular species to the total perennial plant cover typical of adjacent native plant communities, the size of the seed, rooting characteristics (i.e., shallowrooted species), and experience with the species at the NTS (DOE/NV, 2000). Seeded areas were irrigated briefly to promote plant growth.

Table 1 Revegetation activities

\begin{tabular}{|c|c|c|c|c|c|}
\hline & Scientific Name & Common Name & $\begin{array}{c}\text { PLS } \\
\text { Ibs/Acre }\end{array}$ & $\begin{array}{l}\text { Total PLS } \\
\text { lbs of Seed }\end{array}$ & $\begin{array}{c}\text { Approximate Number of } \\
\text { Viable Seeds } / \mathrm{m}^{2}\end{array}$ \\
\hline \multirow[t]{9}{*}{ Shrubs } & Artemisia spinescens & Budsage & 0.1 & 0.8 & 108 \\
\hline & Atriplex confertifolia & Shadscale & 4.4 & 32.0 & 70 \\
\hline & Ephedra nevadensis & Nevada Ephedra & 3.0 & 21.6 & 15 \\
\hline & Ericameria nauseosa & Rubber Rabbitbrush & 1.5 & 11.2 & 151 \\
\hline & Eriognum fasciculatum & Buckwheat & 0.3 & 2.4 & 37 \\
\hline & Grayia spinosa & Spiny Hopsage & 0.5 & 4.0 & 23 \\
\hline & Hymenoclea salsola & Burrobush & 2.2 & 16.0 & 59 \\
\hline & Krascheninnikovia lanata & Winterfat & 4.9 & 36.0 & 69 \\
\hline & Lycium andersonii & Desert Thorn & 0.2 & 1.6 & 10 \\
\hline \multirow[t]{2}{*}{ Grasses } & Achnatherum hymenoides & Indian Ricegrass & 3.4 & 24.8 & 136 \\
\hline & Elymus elymoides & Squirreltail & $\overline{1.0}$ & 7.4 & 48 \\
\hline Forbs & Sphaeralcea ambigua & Globemallow & 0.7 & 4.8 & 81 \\
\hline & Totals & & 22.2 & 162.6 & 807 \\
\hline
\end{tabular}

${ }^{1}$ Pure Live Seed

Details on the background and installation of the lysimeter facility, and the closure and monitoring of U-3ax/bl can be found in Dixon et al. (2000), Fitzmaurice and Levitt (2000), Levitt and Fitzmaurice (2001), and NNSA/NV (2001). Details on the regulatory approval process for the closure of U-3ax/bl can be found in Smith and Fitzmaurice (2001).

\section{Data Summary}

All monitoring data from the lysimeter facility, including drainage, are electronically collected and recorded with data loggers mounted inside the underground monitoring vault (see Figure 5). A direct communication link using coaxial cable communications technology was installed between the vault and a nearby meteorological tower, and a phone line link to the meteorological

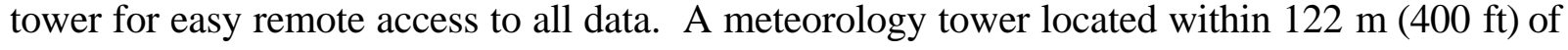
the lysimeter facility has been operational since July 1995. Measurements at the tower include 


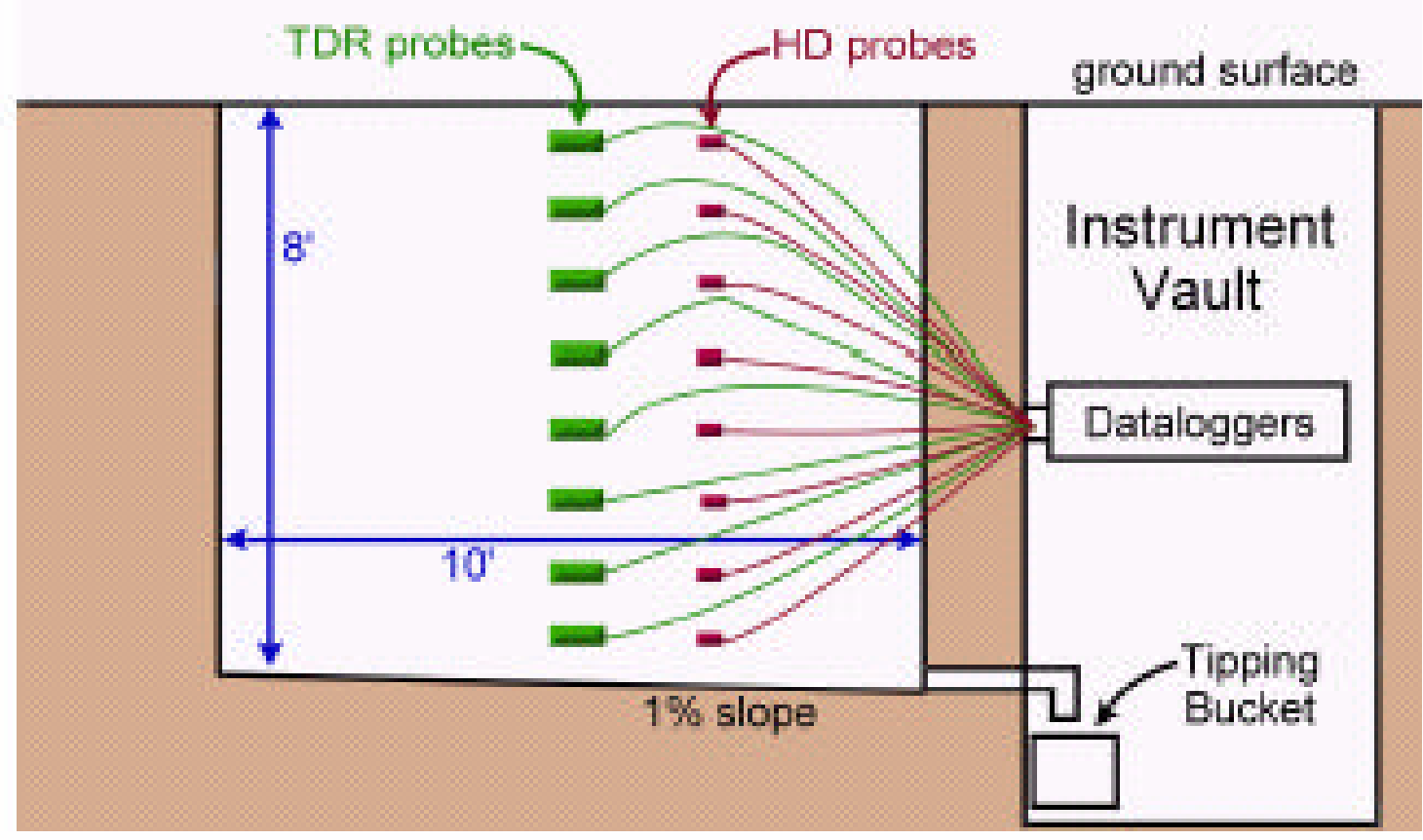

Figure 5 Schematic cross-section of sensor locations in each of the eight drainage and instrumentation vaults

air temperature, wind speed and direction, relative humidity, barometric pressure, and solar radiation. Precipitation is measured in a stand-alone rain gauge near the tower. Meteorology data provide the necessary components to approximate evapotranspiration based on the surface energy balance.

A vegetation survey was conducted on both the U-3ax/bl cap and the seeded lysimeter cells in spring 2002 (see Table 2). Absolute plant cover was estimated by recording the amount of cover within a meter-square quadrant. The measurements from 50 quadrants were used to determine the average cover for the U-3ax/bl cap. Percent cover for U-3ax/bl and the seeded lysimeters as of April 2002 are 6 and 12 percent, respectively. The long-term goal for the vegetative cover is 12 percent and is based on vegetation density of similar native environments. The amount of cover on the lysimeter plots decreased from about 31 percent in June 2001 to 12 percent in April 2002. Although 12 percent cover on the lysimeter plots is higher than expected after one year, species diversity is very low. Vegetation density on the lysimeter plots decreased from over 100 plants/square meter $\left(\mathrm{m}^{2}\right)$ in 2001 to 28 plants $/ \mathrm{m}^{2}$ in 2002 (see Table 3). The most significant decrease in plant numbers was for winterfat, which decreased from 67 plants $/ \mathrm{m}^{2}$ to less than 3 plants $/ \mathrm{m}^{2}$; and Indian ricegrass, which decreased from 11.8 plants $/ \mathrm{m}^{2}$ to 1.3 plants $/ \mathrm{m}^{2}$. Dead plants of winterfat were scattered over the lysimeter plots. Browsers, probably rabbits, had cut the stems. The facility is now fenced with the same fencing design as U-3ax/bl to prevent further consumption of vegetation from browsers. Reseeding of the lysimeters using the original 
Table 2 Average percent cover

\begin{tabular}{|l|c|c|c|c|}
\hline \multirow{2}{*}{ Lifeform } & \multicolumn{4}{|c|}{ \% Cover } \\
\cline { 2 - 5 } & Cover Cap June & $\begin{array}{c}\text { Cover Cap April } \\
2002\end{array}$ & $\begin{array}{c}\text { Lysimeter June } \\
2001\end{array}$ & $\begin{array}{c}\text { Lysimeter April } \\
2002\end{array}$ \\
\hline Seeded Species & 2001 & $\mathbf{6 . 0}$ & $\mathbf{3 1 . 3}$ & $\mathbf{1 2}$ \\
\hline Annuals & $\mathbf{5 . 2}$ & $\mathbf{0}$ & $\mathbf{2 . 0}$ & $\mathbf{0}$ \\
\hline Mulch & $\mathbf{4 3 . 6}$ & $\mathbf{2 4 . 1}$ & $\mathbf{5 1 . 3}$ & $\mathbf{6 3}$ \\
\hline
\end{tabular}

Table 3 Plant density by species

\begin{tabular}{|c|c|c|c|c|}
\hline & & & $\overline{\text { Der }}$ & \\
\hline Lifeform & Scientific Name & Common Name & $\begin{array}{l}\text { Closure Cap } \\
\text { April } 2002\end{array}$ & $\begin{array}{l}\text { Lysimeter } \\
\text { April } 2002\end{array}$ \\
\hline SHRUBS & Artemisia spinescens & Budsage & $\mathbf{0}$ & $\mathbf{7 0 . 0}$ \\
\hline & Atriplex confertifolia & Shadscale & 10.3 & $\mathbf{0}$ \\
\hline & Ephedra nevadensis & Nevada Ephedra & 6.7 & $\mathbf{0}$ \\
\hline & Ericameria nauseosa & Rubber Rabbitbrush & 0.7 & $\mathbf{0}$ \\
\hline & Eriognum fasciculatum & Buckwheat & 4.2 & $\mathbf{0}$ \\
\hline & Grayia spinosa & Spiny Hopsage & 0.1 & $\mathbf{0}$ \\
\hline & Hymenoclea salsola & Burrobush & $\mathbf{0}$ & $\mathbf{0}$ \\
\hline & Krascheninnikovia lanata & Winterfat & 2.7 & 1.8 \\
\hline & Lycium andersonii & Desert Thorn & $\mathbf{0 . 0}$ & $\mathbf{0}$ \\
\hline & Atriplex canescens (not seeded) & Fourwing Saltbush & 0.1 & $\mathbf{0}$ \\
\hline & TOTAL SHRUBS & & 24.8 & 71.8 \\
\hline GRASSES & Achnatherum hymenoides & Indian Ricegrass & 1.3 & $\mathbf{0}$ \\
\hline & Elymus elymoides & Squirreltail & 0.2 & $\mathbf{0}$ \\
\hline & TOTAL GRASSES & & 1.5 & $\mathbf{0}$ \\
\hline FORBS & Sphaeralcea ambigua & Globemallow & $<0.1$ & $\mathbf{0}$ \\
\hline & TOTAL FORBS & & $<0.1$ & $\mathbf{0}$ \\
\hline
\end{tabular}

seed mixture is planned for fall 2002 to increase plant diversity. Because of the below-average precipitation in 2002, supplemental irrigation of $\mathrm{U}-3 \mathrm{ax} / \mathrm{bl}$ is also being considered to maintain the established plant community.

The data indicate that the lysimeters and closure cover have dried rapidly, despite elevated soil water contents (due to dust control) introduced during installation of soil and sensors. Wetting fronts from precipitation events have infiltrated less than 3 feet in the bare cover locations and less than 2 feet at seeded locations (both closure cover and lysimeters) before being returned to the atmosphere via evapotranspiration. Figures 6 and 7 illustrate soil water content with time for 


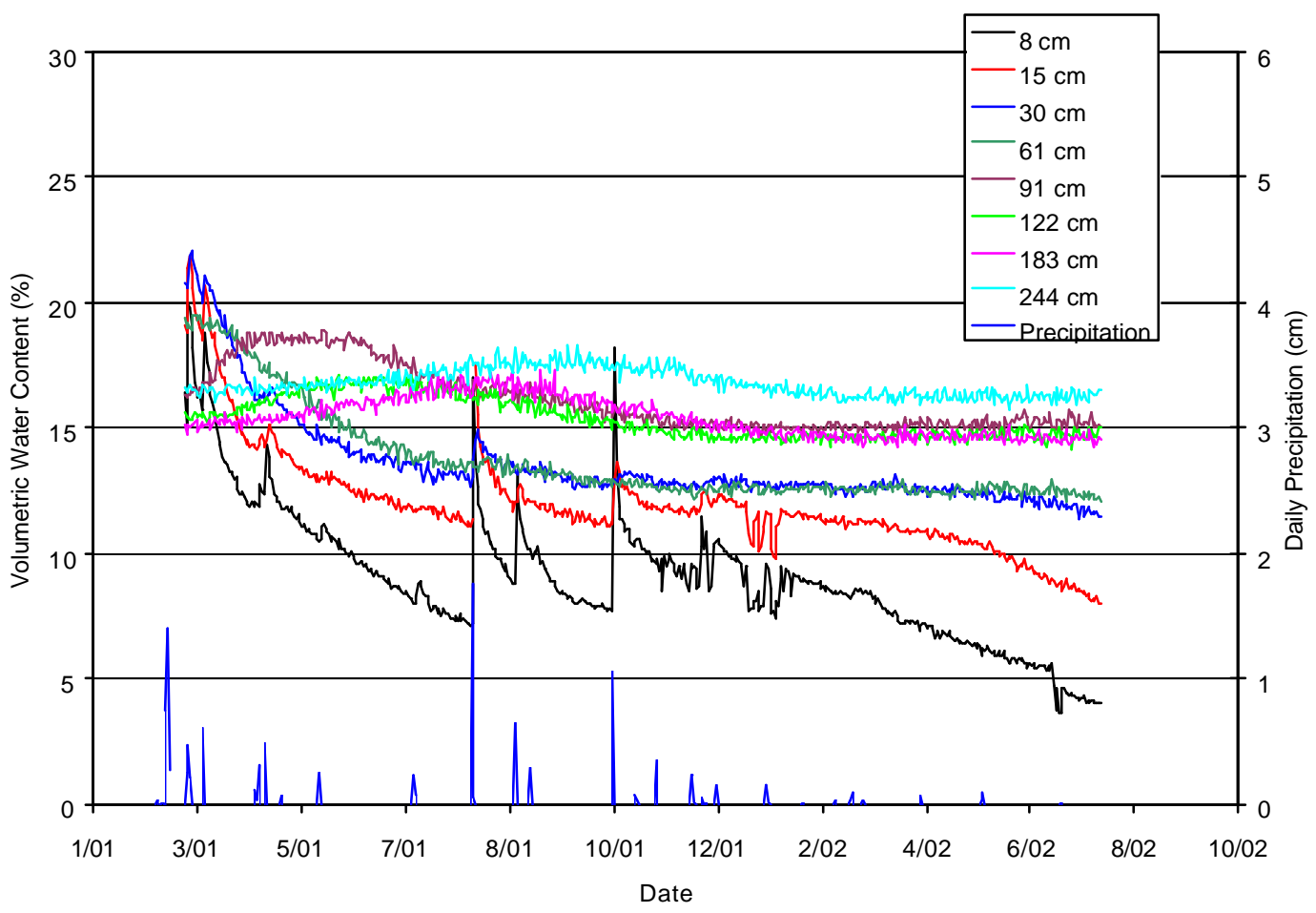

Figure 6 Soil water content in bare drainage lysimeter (A) using TDR system

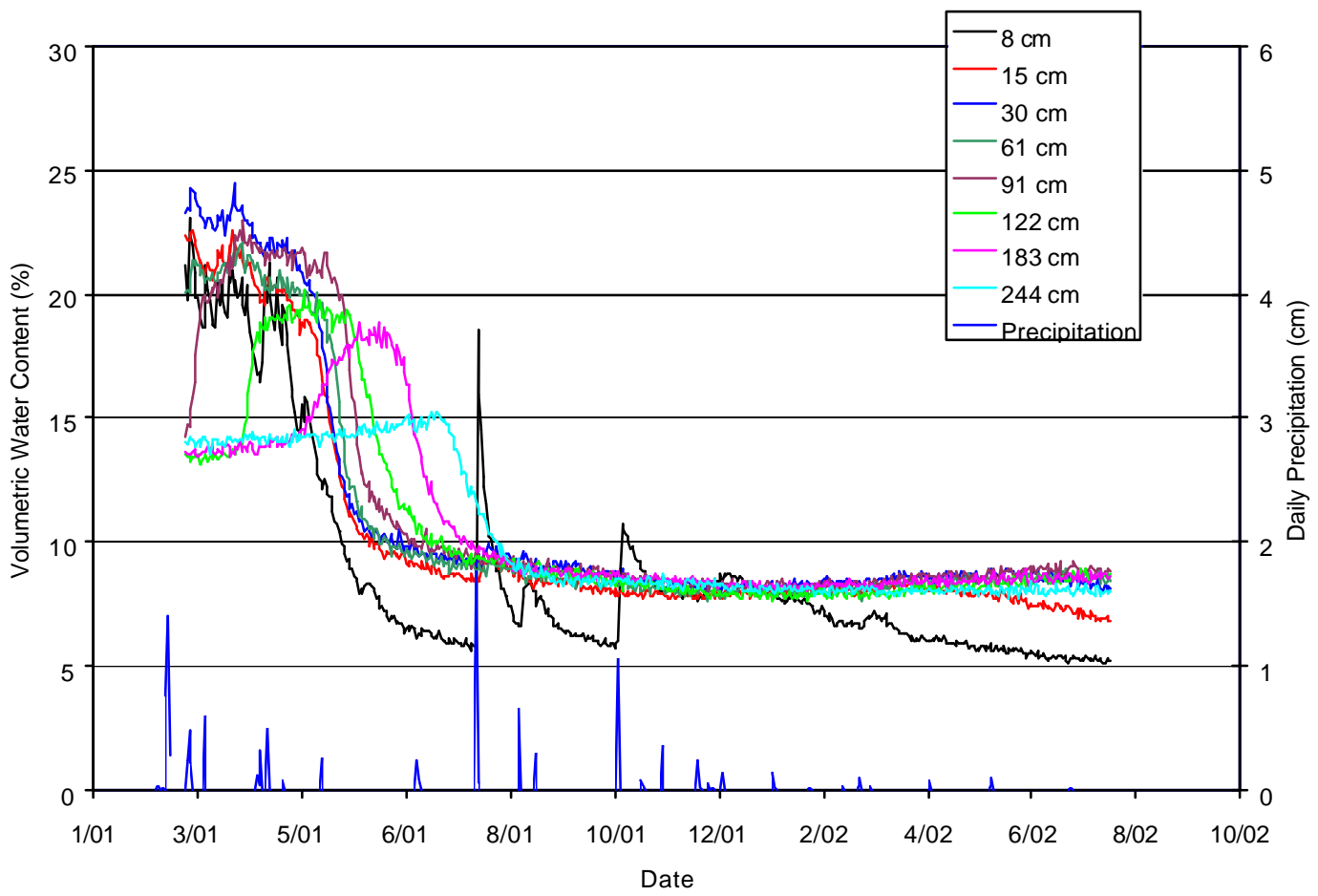

Figure 7 Soil water content in native vegetated drainage lysimeter (E) using TDR system 
lysimeters A and E, respectively. Lysimeter A has a bare-soil surface, while lysimeter E was revegetated with native plant species. These figures illustrate that the vegetated lysimeter is significantly drier than the bare lysimeter. Additionally, the soil water contents in the vegetated plots are essentially uniform below $30 \mathrm{~cm}(1 \mathrm{ft})$, whereas the soil water content generally increases with depth in the bare lysimeters.

Figures 8 and 9 illustrate soil water content with time for U-3ax/bl and show how the soil water content has generally decreased with time as the vegetation on the cap has grown. Comparison of TDR data from the seeded lysimeters and the U-3ax/bl cover indicate that the seeded lysimeters are somewhat drier than the closure cover. This difference can be attributed the much higher vegetation density on the seeded lysimeters as compared to the closure cover. Vegetation surveys conducted in June of 2001 and May of 2002 found the percent cover on the lysimeters to be four and two times higher than the U-3ax/bl cover, respectively. This difference is the result of a higher germination success on the lysimeters.

Figure 10 illustrates the total soil water storage with time for all eight lysimeters. Total water storage is the calculated total amount of the depth of water in each lysimeter. If one lysimeter

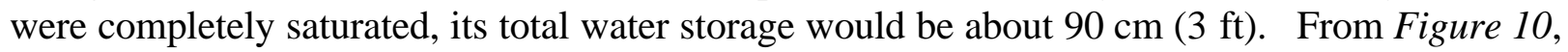
three groups are readily discernable: bare (wettest), native and invaders (driest), and one invader (intermediate). This figure illustrates that 3 of the 4 cells allowed to re-vegetate with invaders species have thus far been nearly as effective as the seeded species in reducing the soil water storage in the top eight feet of soil.

Figure 11 illustrates the bare to native vegetated lysimeter water storage ratio with time, starting at essentially 1 (equal storage) then dipping below 1 for approximately two months due to the irrigation of the vegetated plot. From mid-May 2001, this ratio curve rises sharply as the vegetation grows and transpires water from the lysimeter. The storage ratio curve leveled off in the fall of 2001 to about 1.7 and decreased slowly to its current ratio of approximately 1.6.

Figures 12 and 13 illustrate soil water potential with time at various depths in lysimeters A and E. Note the sensitivity of these sensors to rainfall, where potential can rapidly change by orders of magnitude. Although soil water content is conceptually easier to understand than soil water potential, measurements of water potential are more important for understanding the movement of water in waste covers. These figures generally indicate an upward matric potential gradient. Additionally, some locations within the vegetated lysimeter are dry beyond the measurement range of the senor and show the evapotranspiration effects of drying visible to the bottom of the lysimeter $(2.4 \mathrm{~m}[8 \mathrm{ft}]$ deep).

\section{Conclusions}

The data collected from the drainage lysimeter facility and instrumented U-3ax/bl cover may provide valuable information for the design of landfill covers in arid environments. The nearly two years of data collected from these facilities indicate that all sensors are operating properly and the facilities are performing well. Due to the below average precipitation conditions, the 


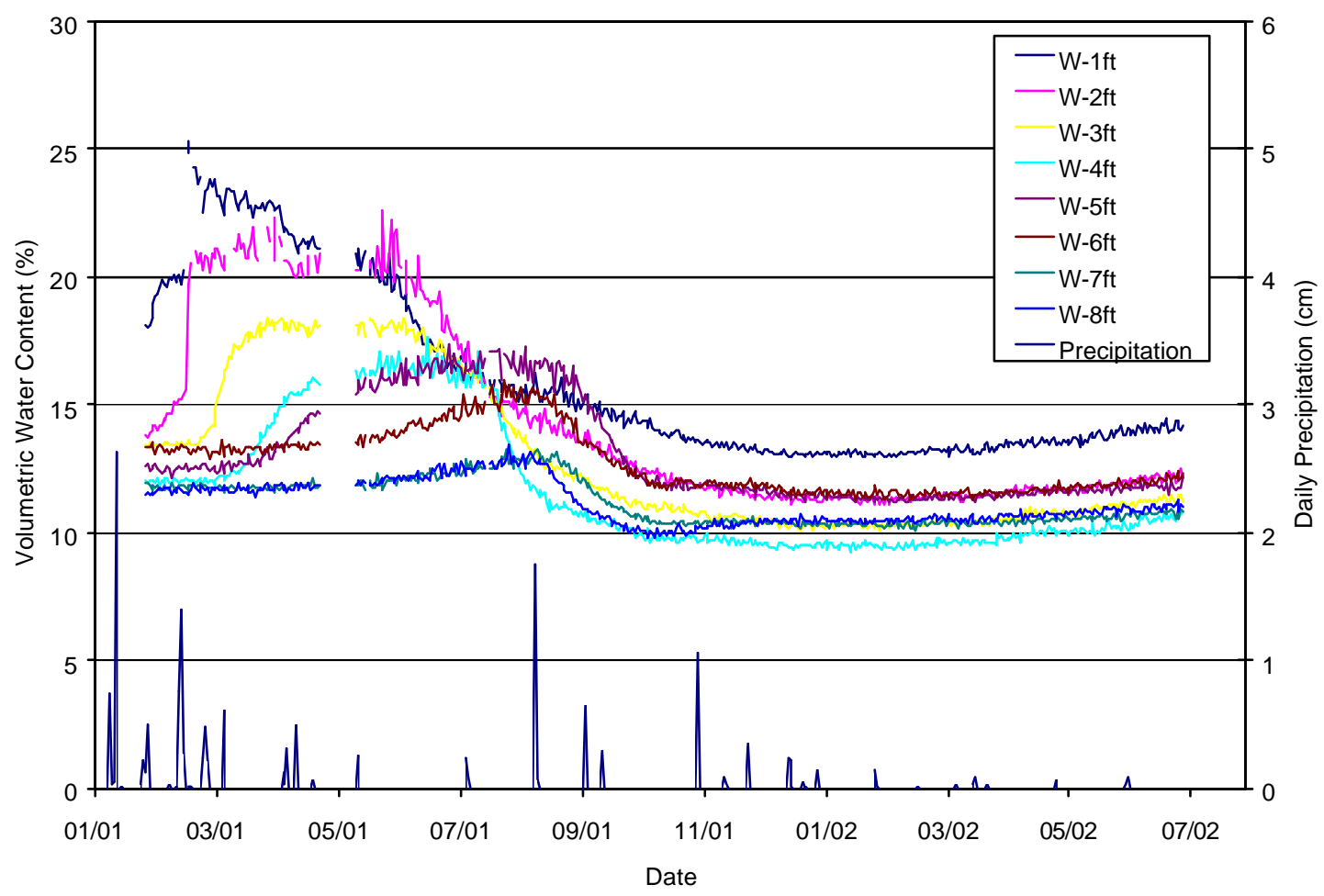

Figure 8 Soil water content in U-3ax/bl cover (west station) using TDR system

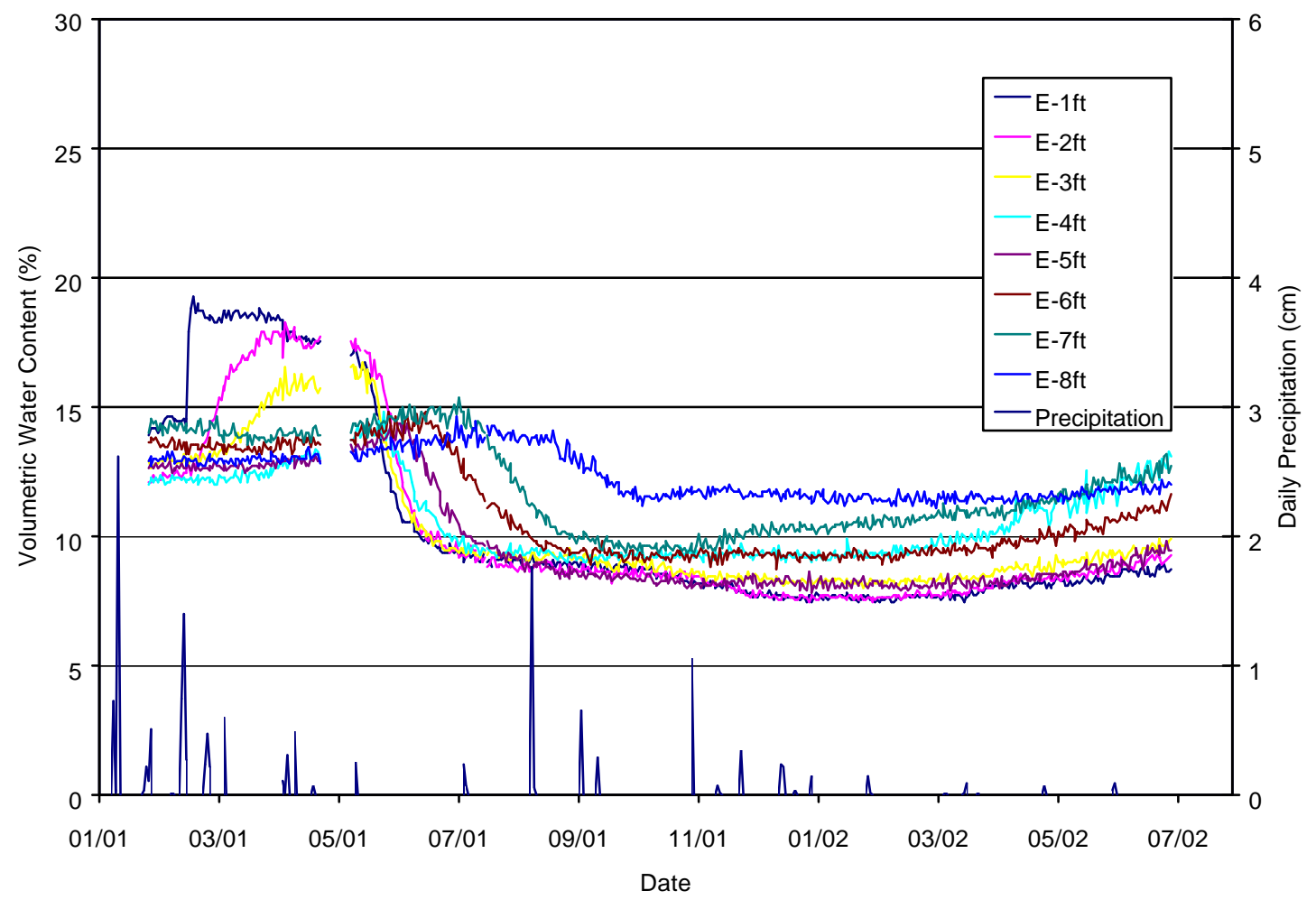

Figure 9 Soil water content in U-3ax/bl cover (east station) using TDR system 


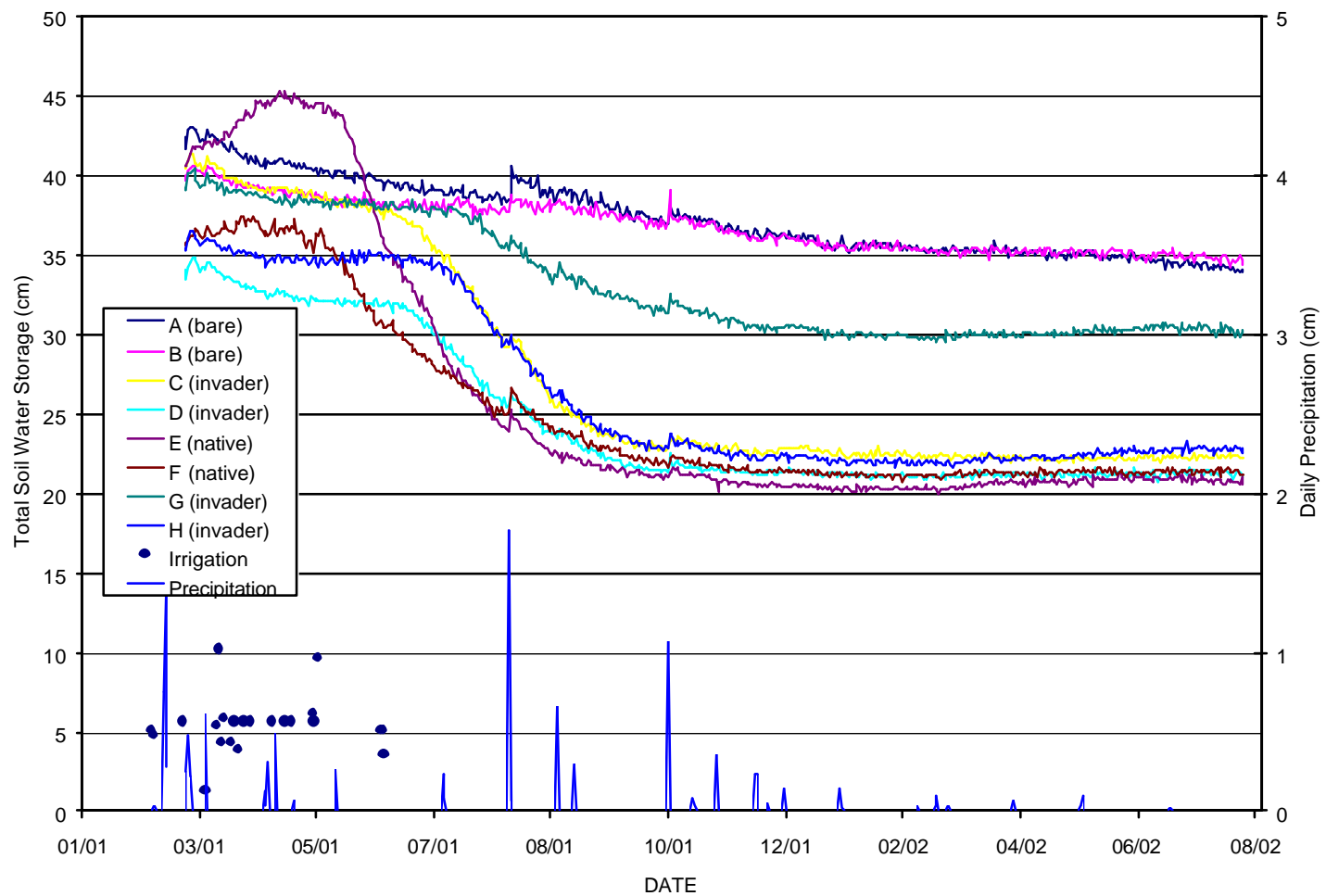

Figure 10 Total soil water storage in drainage lysimeters

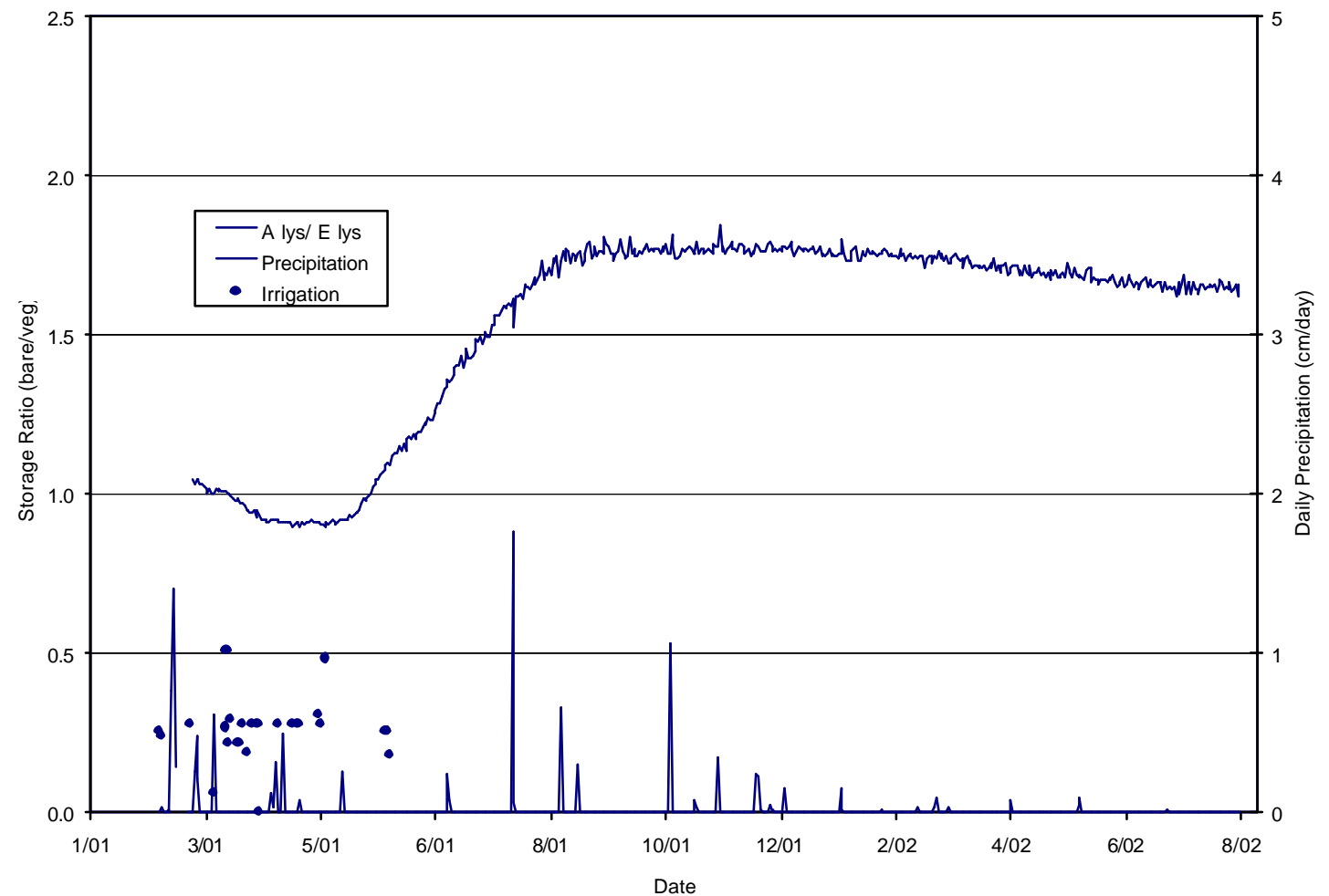

Figure 11 Soil water storage ratio (bare to native vegetated) 


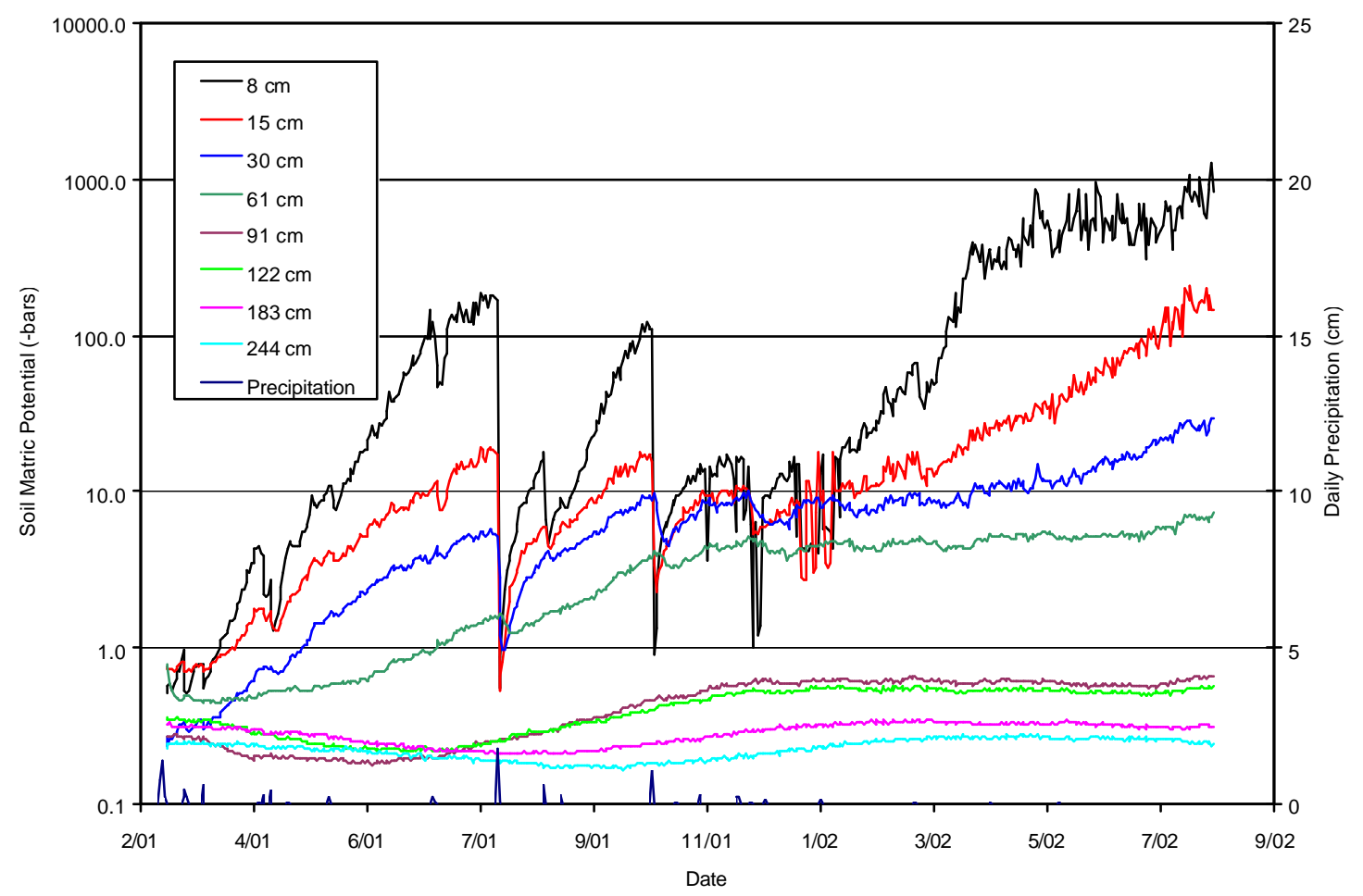

Figure 12 Water potential in lysimeter A (bare soil)

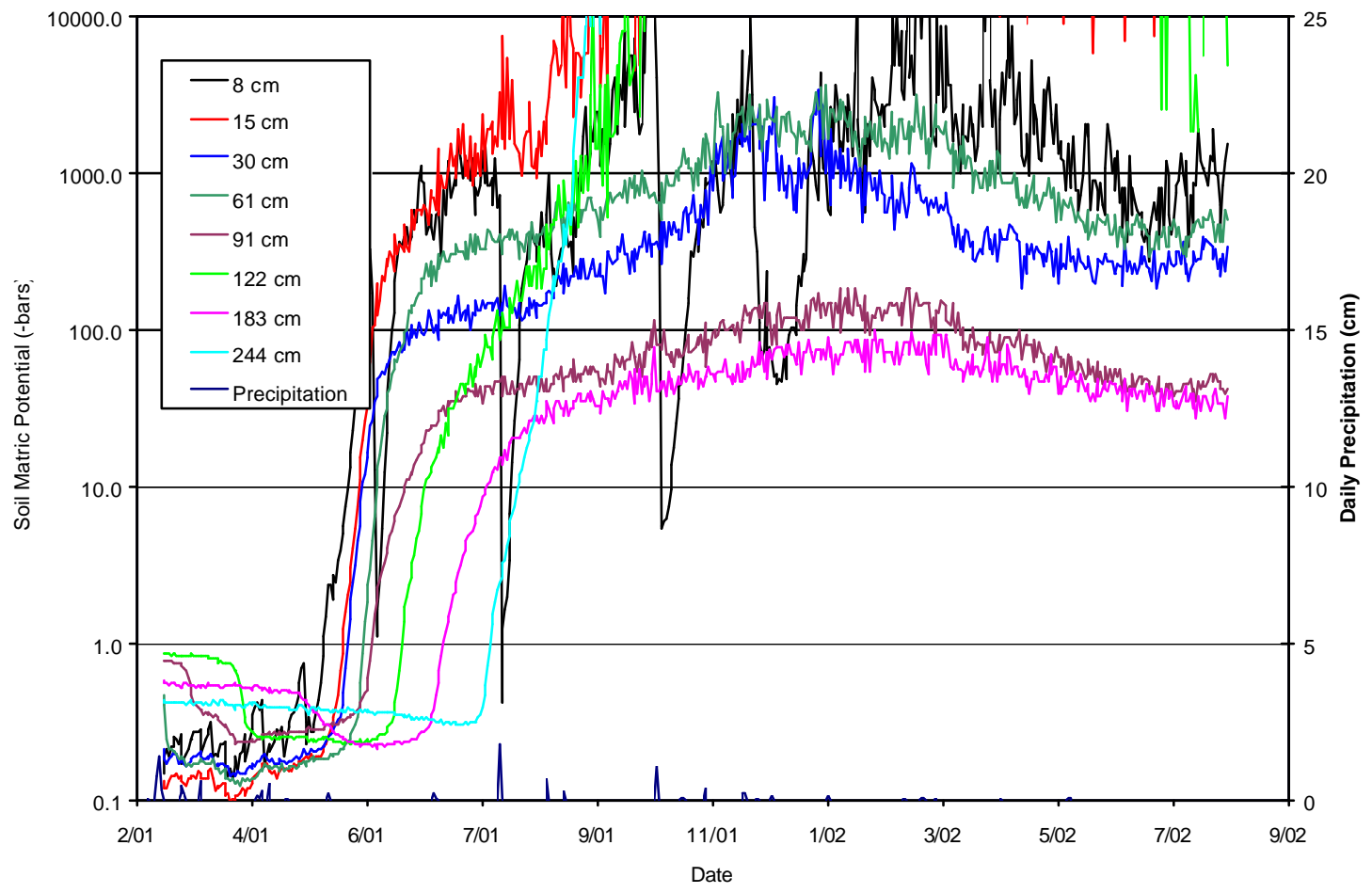

Figure 13 Water potential in lysimeter $\mathbf{E}$ (native vegetation) 
primary concern at these facilities thus far has been the health of the plant community. Reseeding of vegetated lysimeters due to consumption of vegetation by browsers is planned for fall 2002 (facility now fenced) while supplemental irrigation of vegetation on U-3ax/bl is also being considered. Experience gained to date suggests that contingency plans for supplemental irrigation or reseeding and routine vegetation surveys should be accounted for in the planning stages of deploying an ET cover.

Data from the drainage lysimeter facility indicate that surface treatments are a key component of performance of monolayer closure covers. This is illustrated in Figure 11 which shows the current bare to seeded cover soil water storage ratio as 1.6 to 1 (i.e., the bare cover treatment is holding 1.6 times the water than the seeded cover treatment). Somewhat surprisingly, three of the four invader species treatment cells have been nearly as effective as the seeded cells in removing soil water (see Figure 10). It may then be questioned whether the expense of seeding landfill covers is warranted. Although thus far the invader species cells have performed well, the spatial density of invader species growth and therefore effectiveness over a multi-acre cover, is uncertain. However, these data do suggest that a loss of seeded vegetation may be compensated for by the growth of invader species.

\section{Future Work}

Funding for long-term enhanced precipitation (irrigation) is currently being pursued. Irrigation of some of the lysimeters will help define the limits of monolayer-ET cap performance by evaluating what level of precipitation will result in drainage. Reseeding of the native vegetation lysimeters is planned for fall 2002 to increase the plant diversity. Future work at this facility may also include studies of root growth and deployment of a surface treatment on lysimeters $G$ and $\mathrm{H}$.

\section{References}

Dixon, J. M., D. G. Levitt, and S. E. Rawlinson, 2000. “Alternative Site Technology Deployment--Monitoring System for the U-3ax/bl Disposal Unit at the Nevada Test Site." In: Proceedings of the 36th Annual Engineering Geology and Geotechnical Engineering Symposium: Soil and Water Issues for the Arid West.

DOE/NV (U.S. Department of Energy/Nevada Operations Office), 2000. Closure Plan for Corrective Action Unit 110: Area 3 RWMS U-3ax/bl Disposal Site, Nevada Test Site, Nevada. DOE/NV--647. Environmental Restoration Division, U.S. Department of Energy, Nevada Operations Office, Las Vegas, Nevada.

Dwyer, S. F., 1998. "Alternative Landfill Cover Pass the Test.” Civil Engineering, September 1998.

Fitzmaurice, T. M., and D. G. Levitt, 2000. "Deployment of an Alternative Closure Cover and Monitoring System for Corrective Action Units in Nevada." [Abstract Page 159].

Levitt, D. G., and T. M. Fitzmaurice, 2001. "Deployment of an Alternative Closure Cover and Monitoring System at the Mixed Waste Disposal Unit U-3ax/bl at the Nevada Test Site." In: Proceedings of the Waste Management '01 Conference, Tucson, Arizona. 
Levitt, D. G., C. F. Lohrstorfer, M. J. Sully, and J. M. Ginanni, 1996. "An Arid Zone Lysimeter Facility for Performance Assessment and Closure Investigations at the Nevada Test Site." In: Proceedings of Waste Management '96 Conference, Tucson, Arizona.

NNSA/NV (U.S. Department of Energy, National Nuclear Security Administration Nevada Operations Office), 2001. Closure Report for Corrective Action Unit 110, Area 3 RWMS U-3ax/bl Disposal Unit, Nevada Test Site, Nevada. DOE/NV--733. NNSA/NV, Las Vegas, Nevada.

O’Donnell, E., 1998. "The Results of 12 Years of Performance Monitoring of Engineered Covers in Large-Scale Lysimeters at a Humid Region Site, Beltsville, Maryland.” In: Proceedings of the Fall 1998 Meetings of the American Geophysical Union, San Francisco, California.

Schmeltzer, J. S., L. E. Barker, and D. O. Blout, 1996. Site Characterization Data from the U-3ax/bl Exploratory Boreholes at the Nevada Test Site. DOE/NV/11718--003. Bechtel Nevada, Las Vegas, Nevada.

Smith, J. L., and T. M. Fitzmaurice, 2001. "Regulatory Acceptance of Monolayer Vegetative Cover for the Mixed Waste Disposal Unit U-3ax/bl at the Nevada Test Site.” In: Proceedings of the 2001 International Containment and Remediation Technology Conference and Exhibition. [Abstract \#131]. 


\section{DISTRIBUTION LIST}

U.S. Department of Energy

National Nuclear Security Administration

Nevada Site Office

Technical Library

P.O. Box 98518

Las Vegas, NV 89193-8518

U.S. Department of Energy

National Nuclear Security Administration

Nevada Site Office

Public Reading Facility

P.O. Box 98518

Las Vegas, NV 89193-8518

U.S. Department of Energy

Office of Scientific and Technical Information

P.O. Box 62

Oak Ridge, TN 37831-0062
1 copy

1 copy

1 electronic copy 


\section{Attachment 1}

\section{As-Built Drawings for the Area 3 Lysimeter Facility}




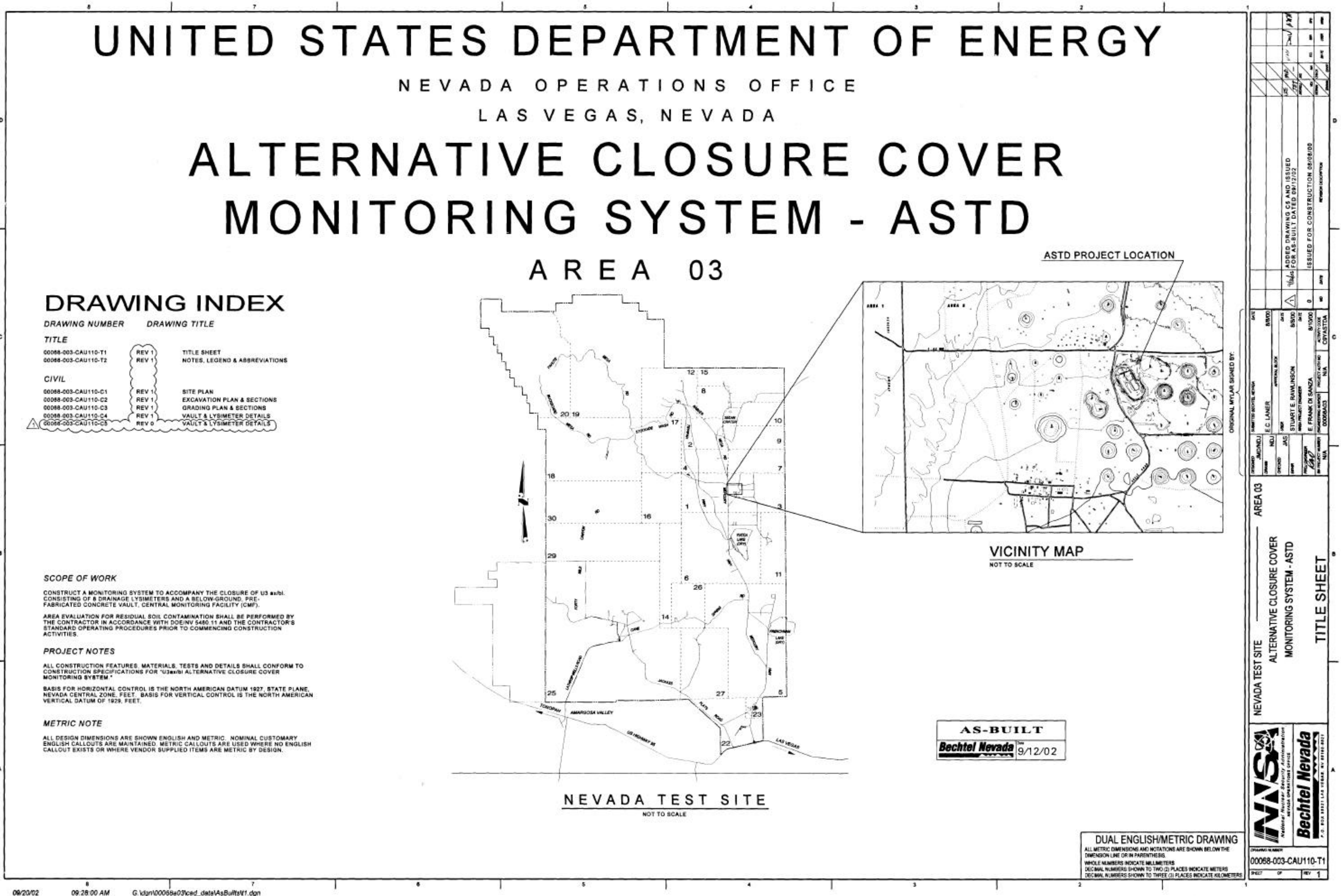


CIVIL NOTES

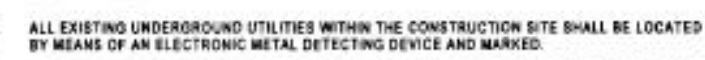

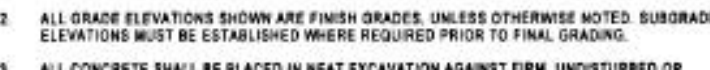

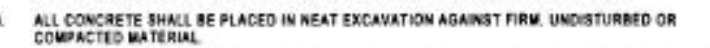

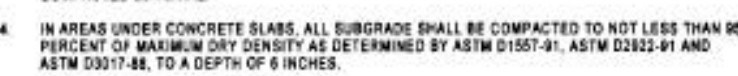

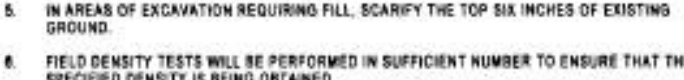

AS-BUILT

Bechtel Nevada $9 / 12 / 02$
CIVIL LEGEND AND SYMBOLS

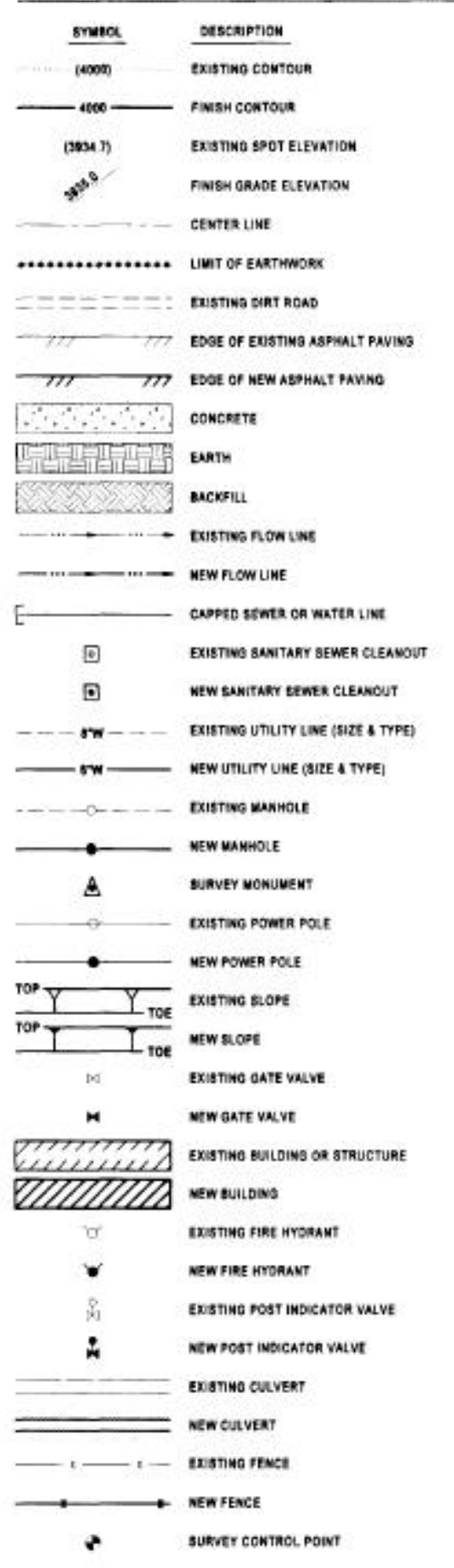

CIVIL LEGEND AND SYMBOLS

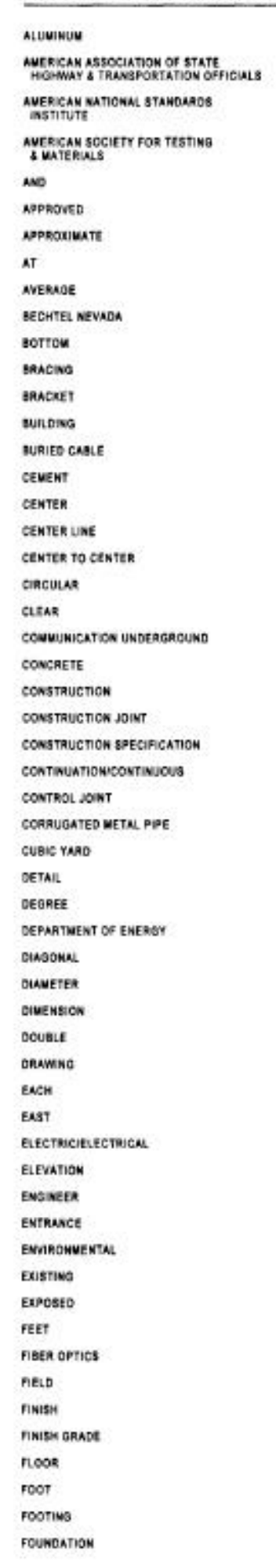

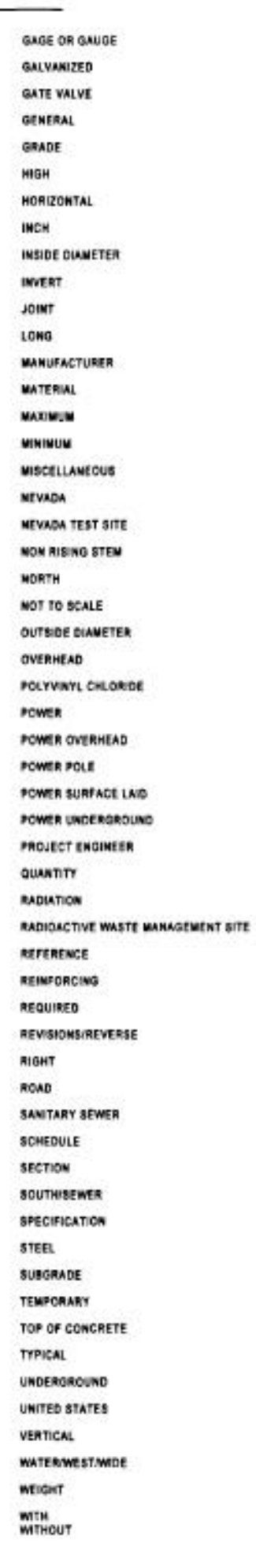




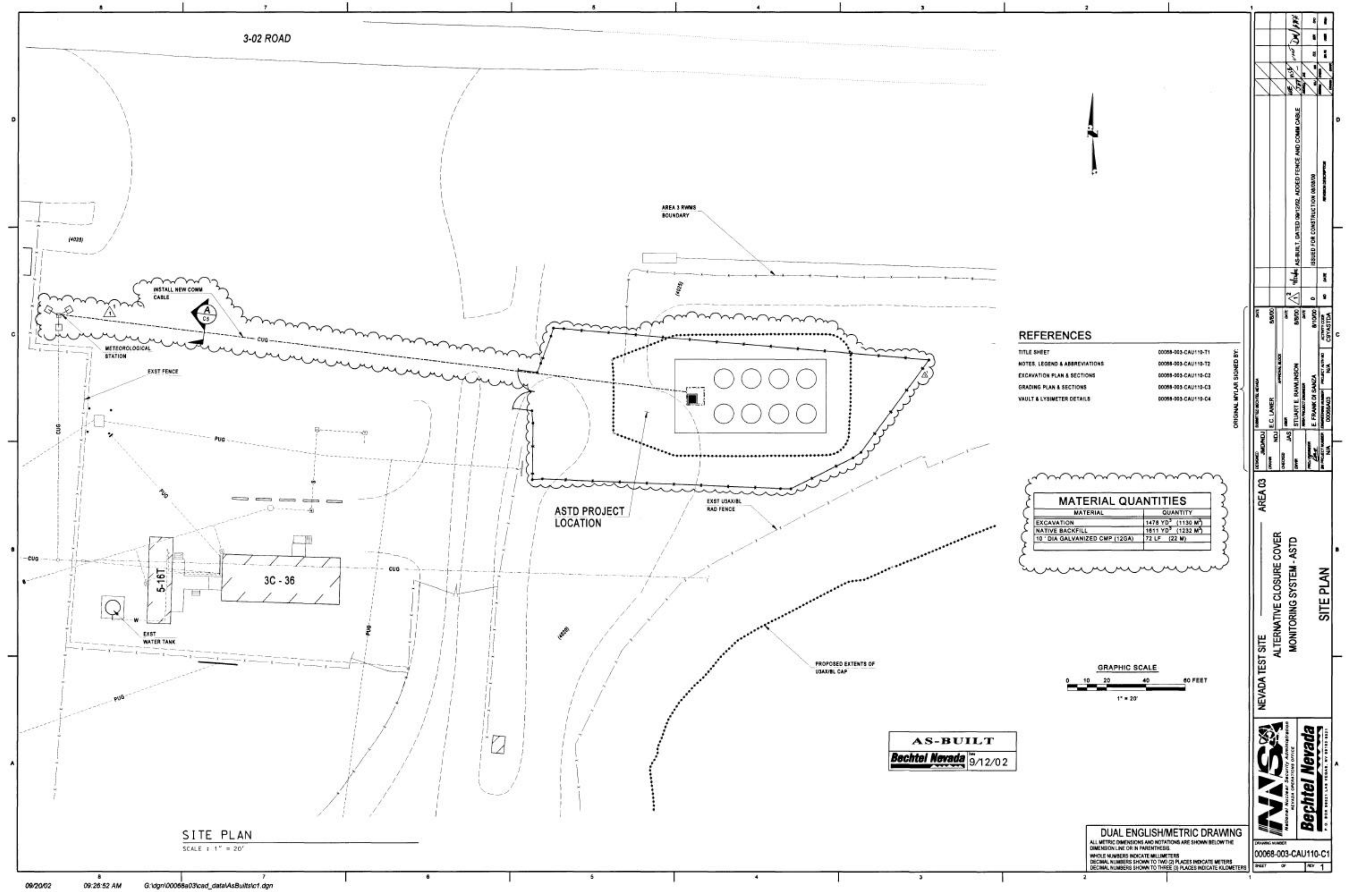




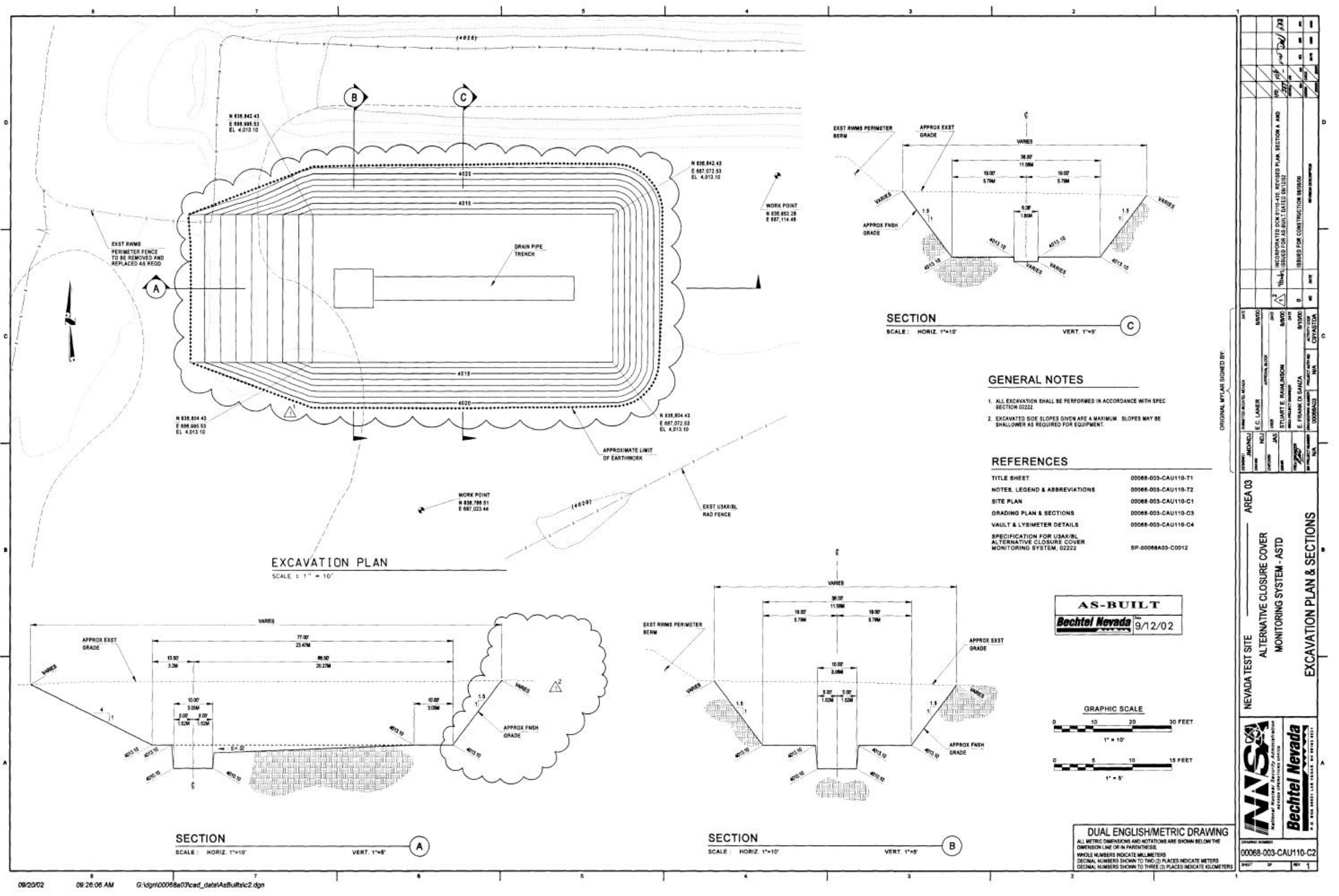




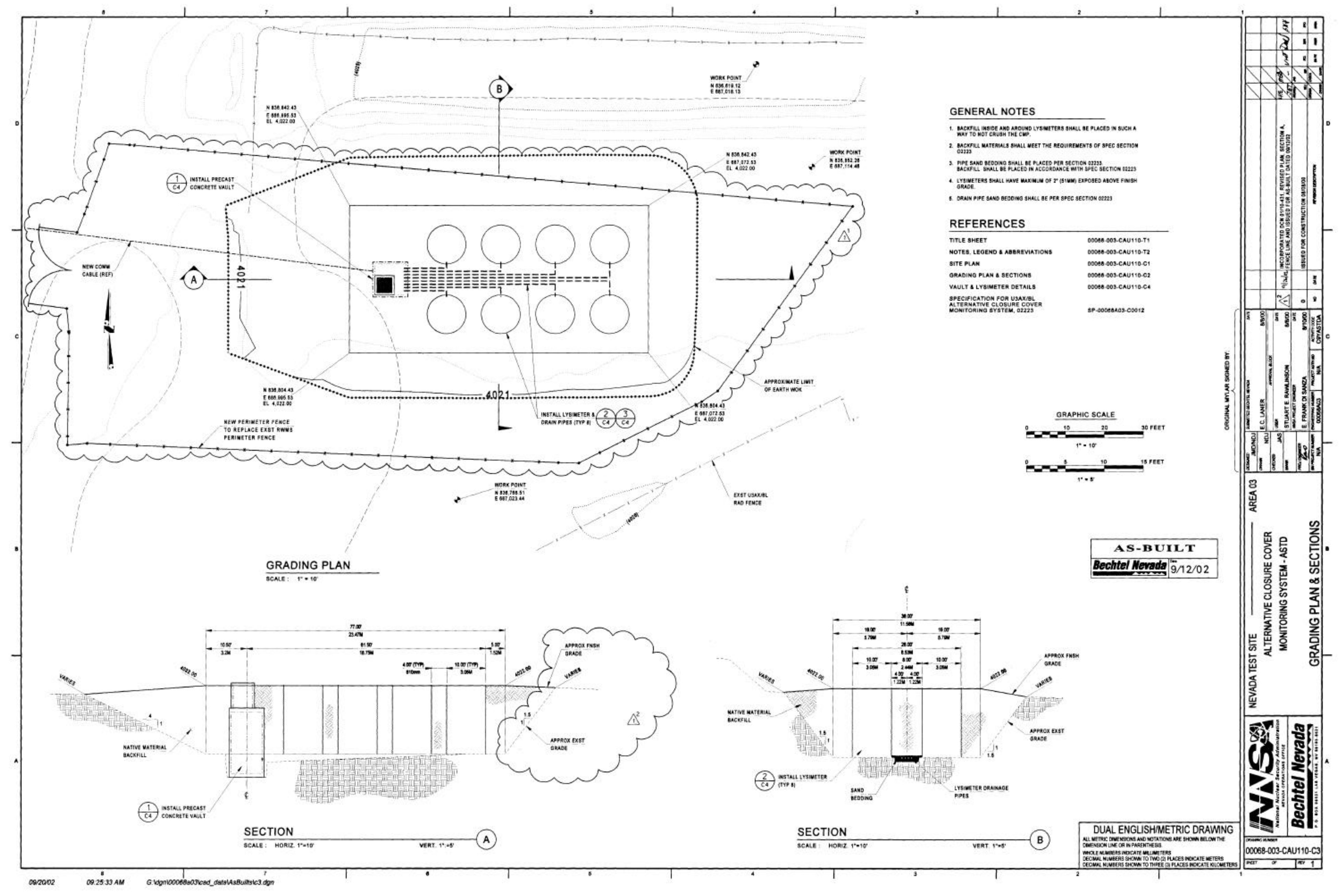




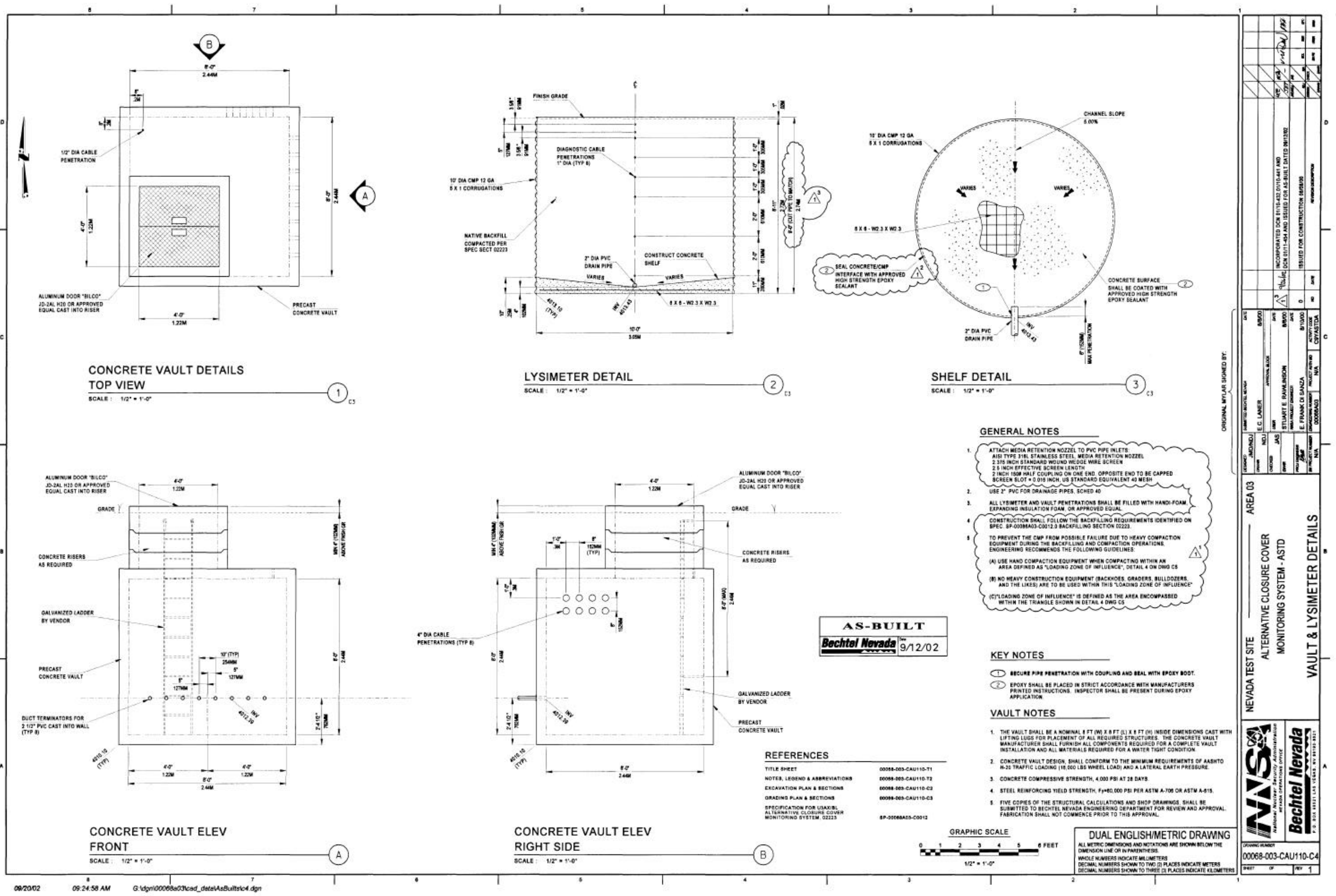




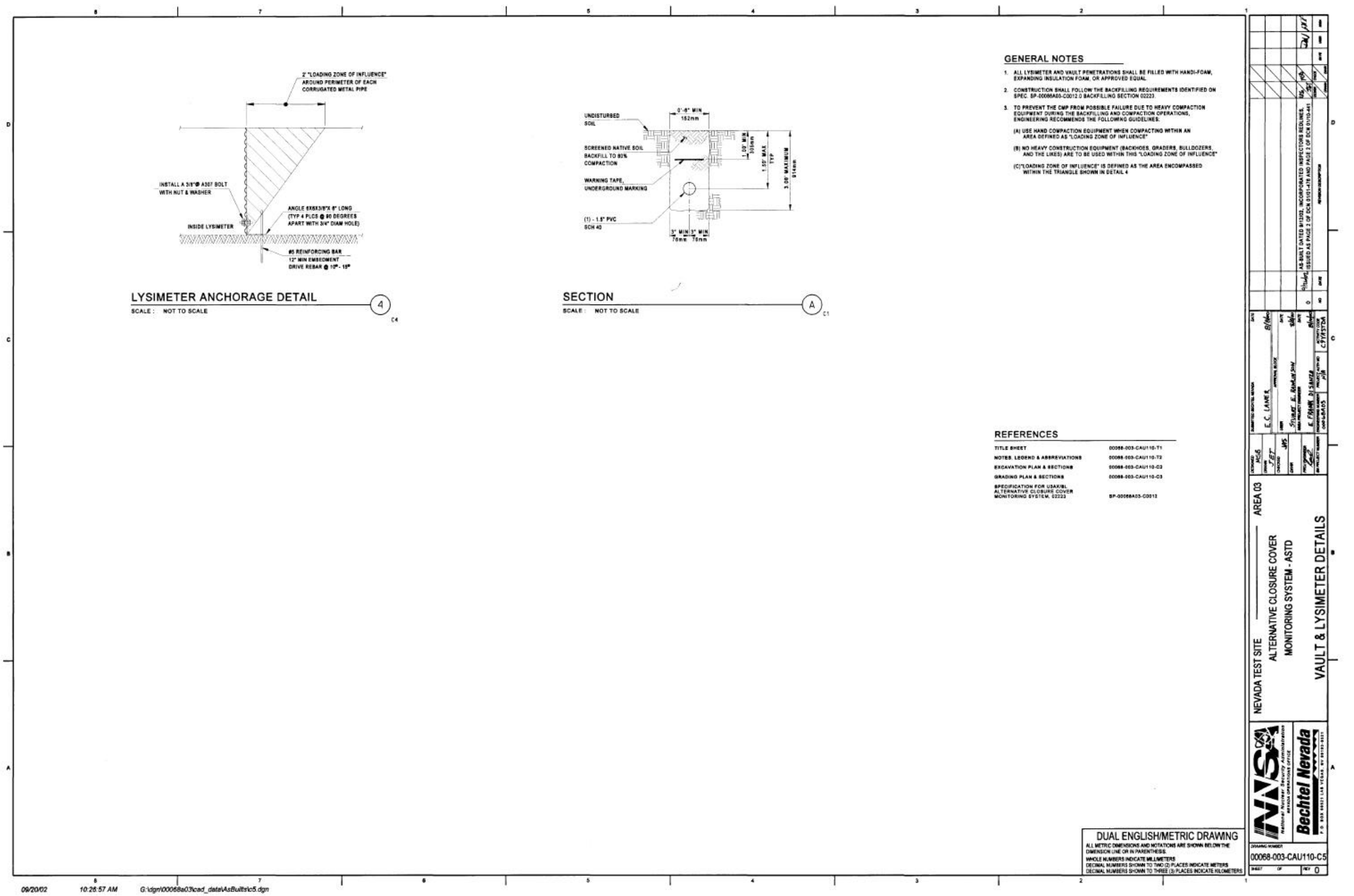

